\title{
Head lice prevalence among households in Norway: importance of spatial variables and individual and household characteristics
}

\author{
BJØRN ARNE RUKKE*, TONE BIRKEMOE, ARNULF SOLENG, \\ HEIDI HEGGEN LINDSTEDT and PREBEN OTTESEN
}

Norwegian Institute of Public Health, Department of Pest Control, Lovisenberggata 8, PO Box 4404 Nydalen, NO-0456 Oslo, Norway

(Received 13 April 2011; revised 12 May 2011; accepted 23 May 2011; first published online 18 fuly 2011)

SUMMARY

Head lice prevalence varies greatly between and within countries, and more knowledge is needed to approach causes of this variation. In the present study, we investigated head lice prevalence among elementary school students and their households in relation to individual and household characteristics as well as spatial variables. The investigation included households from 5 geographically separated municipalities. Present infestations among household members as well as previous infestations in the household were reported in a questionnaire. In elementary school students prevalence was low $(1 \cdot 63 \%)$, but more than one-third of the households $(36.43 \%)$ had previously experienced pediculosis. Prevalence was higher in elementary school students than in other household members, and highest in third-grade children. Prevalence was also influenced by the school attended, which suggested that interactions between children in the same school are important for head lice transmission. Previous occurrence of head lice in homes also increased the risk of present infestation. Prevalence of previous infestations was higher in households with more children and in more densely populated municipalities, indicating that the density of hosts or groups of hosts influences transmission rates. These results demonstrate that information of hosts' spatial distribution as well as household and individual characteristics is needed to better understand head lice population dynamics.

Key words: head lice, pediculosis, prevalence, students, households, spatial variables.

\section{INTRODUCTION}

Head lice (Pediculus capitis De Geer) are obligate, blood-feeding human ectoparasites. They are connected to human hosts during all life stages (Gratz, 1997; Heukelbach, 2010) with physical head-to-head contact as the main route of transmission (Canyon et al. 2002; Mumcuoglu et al. 2009; Heukelbach, 2010). Head lice are widespread throughout the world, with prevalence varying across countries from less than $1 \%$ to well above $50 \%$ (Falagas et al. 2008). The cause of this variation may be due to several factors including the number of head-to-head contacts, diagnostic techniques, eradication methods, pesticide resistance, knowledge regarding head lice and perception of pediculosis as a health problem.

The spatiotemporal distribution of hosts is also likely to influence the prevalence of head lice. Theoretically, prevalence of a macroparasite infestation will increase with rising host density due to the increased probability of parasite transmission (Krasnov et al. 2002; Altizer et al. 2003; Stanko et al. 2006). Only a few empirical studies have investigated this prediction, and their results are divergent (Sorci et al. 1997; Arneberg et al. 1998; Krasnov et al. 2002; Stanko et al .

* Corresponding author: Tel: +4721076595. Fax: +47210765 31. E-mail: bjorn.arne.rukke@fhi.no
2002, 2006; Mbora and Mcpeek, 2009). Head lice may also be considered as a species living on discrete habitat patches represented by groups of closely interacting human hosts. Metapopulation theory (e.g. Hanski and Thomas, 1994; Hanski, 1999) implies that isolated and small habitat patches consisting of few human hosts should have lower head lice prevalence than less isolated and large patches with many hosts, due to higher extinction and lower colonization and re-colonization rates in the former scenario.

More studies are needed to approach the importance of spatial variables in head lice population dynamics. The aim of the present study was to investigate the importance of spatial distribution of human hosts in combination with individual and household characteristics on head lice prevalence. To achieve this purpose, data on present prevalence in elementary school students and previous prevalence among their households were collected from 5 Norwegian municipalities with different human population densities.

\section{MATERIALS AND METHODS}

\section{Study area}

The study was carried out in 5 Norwegian municipalities (Fig. 1). Oslo had the largest number of

Parasitology (2011), 138, 1296-1304. C Cambridge University Press 2011. The online version of this article is published within an Open Access environment subject to the conditions of the Creative Commons Attribution-NonCommercial-ShareAlike licence < http://creativecommons. org/licenses/by-nc-sa/2.5/>. The written permission of Cambridge University Press must be obtained for commercial re-use. 


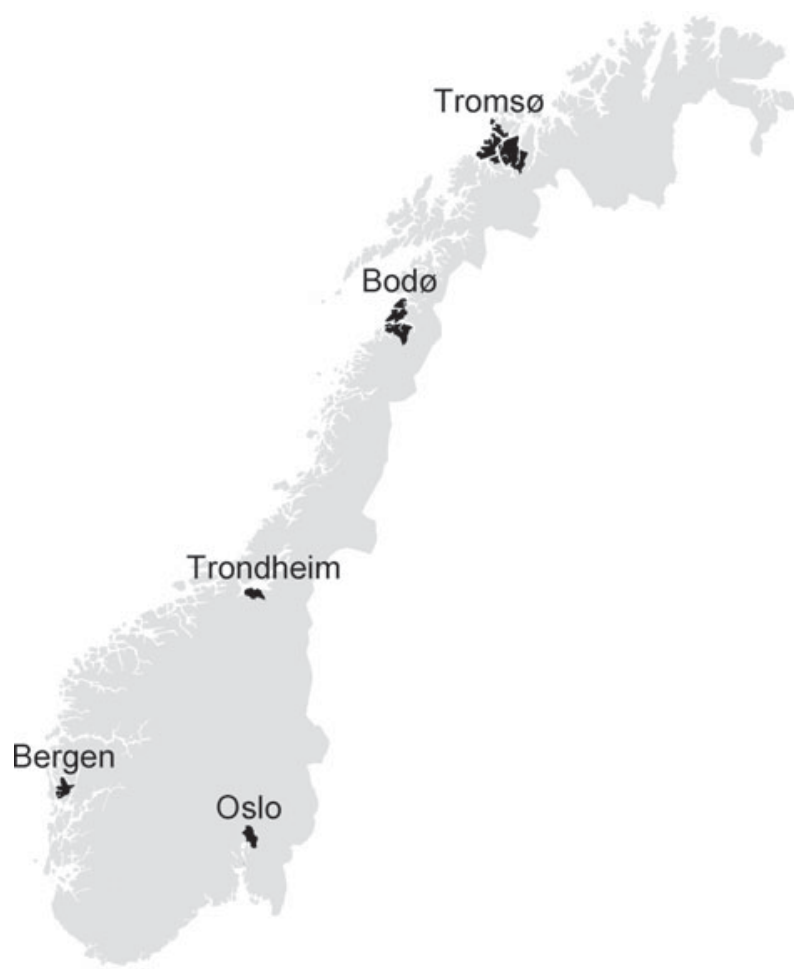

Fig. 1. The municipalities where participants were recruited. Basic map data: Norwegian Mapping Authority (cc-by-sa-3.0).

inhabitants (Statistics Norway, 2008), most elementary schools (Pedlex Norsk Skoleinformasjon, 2010) and the largest area of urban settlement (Norwegian Mapping Authority, 2010) (Table 1). Urban settlement area is defined by Statistics Norway as a hub of buildings inhabited by at least 200 persons where the distances between buildings do not exceed 50 metres. The average number of students in elementary schools in Oslo, Bergen, Trondheim, Bodø and Tromsø was 410, 320, 320, 220 and 170, respectively (Pedlex Norsk Skoleinformasjon, 2010).

\section{Participation}

Households were asked to participate in the study from a total of 42 elementary schools (first through seventh grade, age 5-12) representing 16367 students. Nine schools were located in Oslo, 11 in Bergen, 9 in Trondheim, 5 in Bodø and 8 in Tromsø. All schools were situated in urban settlement areas and had more than 180 students.

\section{Sampling process}

Each child at the schools received an envelope from the teacher addressed to the parents/care takers. Inside the envelope was a white plastic lice comb, a questionnaire and a lice information brochure. The households were asked to examine each of their members with the lice comb and answer the questionnaire.
The presence or absence of head lice, age/grade (elementary school) and sex were reported for each household member. The questionnaire also contained questions regarding previous infestations of head lice in the household and total number of household members.

The presence of head lice was defined as finding living lice on a person's head, which is a more accurate sign of active pediculosis than the presence of nits (Burgess, 1995, 2009; Mumcuoglu et al. 2007; Heukelbach, 2010). To standardize search methods and improve detection rates, all participants received written instructions, both in the covering letter and information brochure, on how to detect head lice with the enclosed comb. One questionnaire per household was returned through the school in an anonymous envelope.

\section{Statistical analyses}

Multivariate, mixed-effect logistic regression models were constructed to investigate the importance of different predictor variables on present prevalence (proportion of infected hosts (Margolis et al. 1982)) among elementary school children and previous prevalence (proportion of households where at least one of its members had a previous infection) among their households. To account for the fact that study units from the same subpopulations or school could be more similar than those from other schools, the school was included as a random-effect variable in each analysis. Because some questionnaires were incomplete, the number of study objects $(N)$ differs between the analyses. Statistical analyses were performed using Stata software version 11 (StataCorp LP, 2009).

\section{Ethical approval}

The Data Inspectorate and Regional Committees for Medical and Health Research Ethics in Norway approved the ethical aspects of the investigation. The study was considered anonymous, as each person was only identified by age, grade (elementary school) and sex.

\section{RESULTS}

\section{Participation}

A total of 6203 households submitted the questionnaire, and among these, 20981 persons were examined for head lice (Table 2). Regarding elementary school children (first to seventh grade), 8145 of 16367 invited participants were examined for an overall participation rate of $49 \cdot 76 \%$. The number of students examined was highest in the third grade (1267 students) and lowest in the seventh grade (1054 students), with an average of 1164 per grade. The 
Table 1. Number of inhabitants and elementary schools, urban settlement area and total land area in the municipalities

\begin{tabular}{llllc}
\hline \hline Municipality & Inhabitants & Elementary schools & Urban settlement $\left(\mathrm{km}^{2}\right)$ & Total land area $\left(\mathrm{km}^{2}\right)$ \\
\hline Oslo & 573000 & 99 & 61 & 454 \\
Bergen & 251000 & 69 & 53 & 465 \\
Trondheim & 168000 & 40 & 31 & 342 \\
Bodø & 46000 & 19 & 9 & 1392 \\
Tromsø & 66000 & 35 & 12 & 2520 \\
\hline \hline
\end{tabular}

Table 2. Number of participating households and household members, grouped by age, in the municipalities

\begin{tabular}{|c|c|c|c|c|c|c|c|}
\hline Municipality & Households & $\begin{array}{l}0-6 \\
\text { years }\end{array}$ & $\begin{array}{l}1 \mathrm{st}-7 \mathrm{th} \\
\text { grade }\end{array}$ & $\begin{array}{l}8 \text { th-10th } \\
\text { grade }\end{array}$ & $\begin{array}{l}16-20 \\
\text { years }\end{array}$ & $\begin{array}{l}>20 \\
\text { years }\end{array}$ & $\begin{array}{l}\text { Total persons } \\
\text { participated }\end{array}$ \\
\hline Oslo & 1611 & 467 & 2076 & 288 & 186 & 2235 & 5252 \\
\hline Bergen & 1509 & 470 & 2063 & 342 & 226 & 2208 & 5309 \\
\hline Trondheim & 1482 & 495 & 1946 & 301 & 156 & 2248 & 5146 \\
\hline Bodø & 604 & 164 & 757 & 107 & 75 & 908 & 2011 \\
\hline Tromsø & 997 & 309 & 1303 & 174 & 104 & 1394 & 3284 \\
\hline Totals & 6203 & 1905 & 8145 & 1212 & 747 & 8972 & 20981 \\
\hline
\end{tabular}

Table 3. Mixed-effect logistic regression model of present head lice prevalence among persons in different age groups with school as a random-effect variable (school estimate: $0 \cdot 782, P<0 \cdot 001$ )

(Odds ratios are in relation to the first category (first through seventh grade). $N=20981$.)

\begin{tabular}{|c|c|c|c|c|}
\hline Variable & $P$-value & Category & Prevalence $(n)$ & Odds ratio $(95 \%-\mathrm{CI})$ \\
\hline \multirow[t]{5}{*}{ Age group } & $<0.001$ & $1 \mathrm{st}-7$ th grade & $1 \cdot 63 \%(8145)$ & 1 \\
\hline & & $0-5$ years & $0 \cdot 52 \%(1905)$ & $0 \cdot 32(0 \cdot 17-0 \cdot 61)$ \\
\hline & & 8 th -10 th grade & $0 \cdot 74 \%(1212)$ & $0.45(0 \cdot 23-0 \cdot 89)$ \\
\hline & & $16-20$ years & $0.67 \%(747)$ & $0 \cdot 41(0 \cdot 17-1 \cdot 02)$ \\
\hline & & $>20$ years & $0 \cdot 51 \%(8972)$ & $0 \cdot 31(0 \cdot 22-0 \cdot 43)$ \\
\hline
\end{tabular}

proportion of participating students ranged from $28 \cdot 53 \%$ to $74 \cdot 86 \%$ across different schools and from $45 \cdot 57 \%$ to $56 \cdot 33 \%$ across different municipalities.

\section{Present prevalence of head lice}

Prevalence among all household members. Among all examined household members, only $0.97 \%$ $(N=20981)$ had an active infestation. The prevalence among elementary school students was $1 \cdot 63 \%$, significantly higher than in other age groups (Table 3). The prevalence at different schools ranged from 0 to $7 \cdot 14 \%$.

Which elementary school children have head lice? The multivariate model demonstrated that children in the third grade had significantly higher risk of pediculosis than students in other grades (Table 4). Additionally, children were 3 times more likely to have head lice if their household had previously experienced pediculosis. Elementary school children from households with 2 children had nearly significantly lower probability of pediculosis compared to those with 1 child. The total number of household members, number of adults in a household, number of students per school, sex and municipality had no significant effect on prevalence in this analysis. School, included as random-effect variable, significantly improved the multivariate model (estimate: $0.653, P<0 \cdot 001$ ), which indicates that school on its own was an important factor explaining head lice prevalence.

\section{Previous prevalence of head lice}

Previous prevalence in households. A total of $36.43 \%$ of the participating households $(N=6026)$ had previously experienced head lice infestation. The highest proportion was in Bergen (45.19\%) and the lowest in Bodø $(22 \cdot 39 \%)$. Of the households with previous experience of head lice, $62 \cdot 36 \%$ had been infested once, $25 \cdot 88 \%$ had been infested twice, $7 \cdot 89 \%$ three times and $3 \cdot 85 \%$ four times or more (Fig. 2). Previous prevalence of head lice in households ranged from $15 \cdot 38 \%$ to $59 \cdot 38 \%$ (average: $35 \cdot 54 \%$ ) across schools. 
Table 4. Multivariate, mixed-effect logistic regression model of present prevalence of head lice among elementary school children with school as a random-effect variable

(Odds ratios are in relation to the first category of each variable. $N=7679$.)

\begin{tabular}{|c|c|c|c|c|}
\hline Variable & $P$-value & Category & Prevalence $(n)$ & Odds ratio $(95 \%-\mathrm{CI})$ \\
\hline Number of household members & $0 \cdot 462$ & $\begin{array}{l}2 \text { or } 3 \text { persons } \\
4 \text { persons } \\
>4 \text { persons }\end{array}$ & $\begin{array}{l}2 \cdot 01 \%(1342) \\
1 \cdot 23 \%(3570) \\
1 \cdot 73 \%(2767)\end{array}$ & $\begin{array}{l}1 \\
1 \cdot 09(0 \cdot 39-3 \cdot 07) \\
0 \cdot 75(0 \cdot 12-4 \cdot 69)\end{array}$ \\
\hline Number of children (persons $<18$ years) & $0 \cdot 079$ & $\begin{array}{l}1 \text { child } \\
2 \text { children } \\
3 \text { children } \\
>3 \text { children }\end{array}$ & $\begin{array}{l}2 \cdot 41 \%(956) \\
1 \cdot 19 \%(4027) \\
1 \cdot 62 \%(2164) \\
2 \cdot 44 \%(532)\end{array}$ & $\begin{array}{l}1 \\
0 \cdot 44(0 \cdot 19-1 \cdot 06) \\
0 \cdot 77(0 \cdot 15-4 \cdot 04) \\
1 \cdot 07(0 \cdot 18-6 \cdot 20)\end{array}$ \\
\hline Number of adults (persons $>18$ years) & $0 \cdot 754$ & $\begin{array}{l}1 \text { adult } \\
2 \text { adults } \\
>2 \text { adults }\end{array}$ & $\begin{array}{l}1 \cdot 94 \%(979) \\
1 \cdot 47 \%(6345) \\
1 \cdot 97 \%(355)\end{array}$ & $\begin{array}{l}1 \\
0 \cdot 87(0 \cdot 40-1 \cdot 89) \\
1 \cdot 13(0 \cdot 26-4 \cdot 94)\end{array}$ \\
\hline Sex & $0 \cdot 306$ & $\begin{array}{l}\text { Male } \\
\text { Female }\end{array}$ & $\begin{array}{l}1 \cdot 35 \%(3770) \\
1 \cdot 74 \%(3909)\end{array}$ & $\begin{array}{l}1 \\
1 \cdot 21(0 \cdot 84-1 \cdot 76)\end{array}$ \\
\hline Grade & $0 \cdot 001$ & $\begin{array}{l}\text { 1. grade } \\
\text { 2. grade } \\
\text { 3. grade } \\
\text { 4. grade } \\
\text { 5. grade } \\
\text { 6. grade } \\
\text { 7. grade }\end{array}$ & $\begin{array}{l}0 \cdot 97 \%(1138) \\
0 \cdot 84 \%(1066) \\
3 \cdot 01 \%(1196) \\
1 \cdot 45 \%(1103) \\
2 \cdot 01 \%(1144) \\
1 \cdot 26 \%(1034) \\
1 \cdot 10 \%(998)\end{array}$ & $\begin{array}{l}1 \\
0 \cdot 85(0 \cdot 35-2 \cdot 07) \\
2 \cdot 86(1 \cdot 43-5 \cdot 72) \\
1 \cdot 27(0 \cdot 58-2 \cdot 77) \\
1 \cdot 65(0 \cdot 79-3 \cdot 45) \\
1 \cdot 06(0 \cdot 47-2 \cdot 41) \\
0 \cdot 89(0 \cdot 38-2 \cdot 10)\end{array}$ \\
\hline Municipality & $0 \cdot 416$ & $\begin{array}{l}\text { Tromsø } \\
\text { Bodø } \\
\text { Trondheim } \\
\text { Bergen } \\
\text { Oslo }\end{array}$ & $\begin{array}{l}0 \cdot 98 \%(1220) \\
0 \cdot 82 \%(733) \\
1 \cdot 62 \%(1856) \\
1 \cdot 53 \%(1962) \\
2 \cdot 15 \%(1908)\end{array}$ & $\begin{array}{l}1 \\
0 \cdot 78(0 \cdot 20-2 \cdot 99) \\
1 \cdot 87(0 \cdot 58-6 \cdot 02) \\
1 \cdot 53(0 \cdot 58-4 \cdot 05) \\
2 \cdot 53(0 \cdot 81-7 \cdot 90)\end{array}$ \\
\hline Previous presence of head lice & $<0 \cdot 001$ & $\begin{array}{l}\text { No } \\
\text { Yes }\end{array}$ & $\begin{array}{l}0 \cdot 86 \%(4661) \\
2 \cdot 62 \%(3018)\end{array}$ & $\begin{array}{l}1 \\
2 \cdot 90(1 \cdot 94-4 \cdot 35)\end{array}$ \\
\hline Number of students per school & $0 \cdot 498$ & & & $1 \cdot 00(1 \cdot 00-1 \cdot 00)$ \\
\hline
\end{tabular}

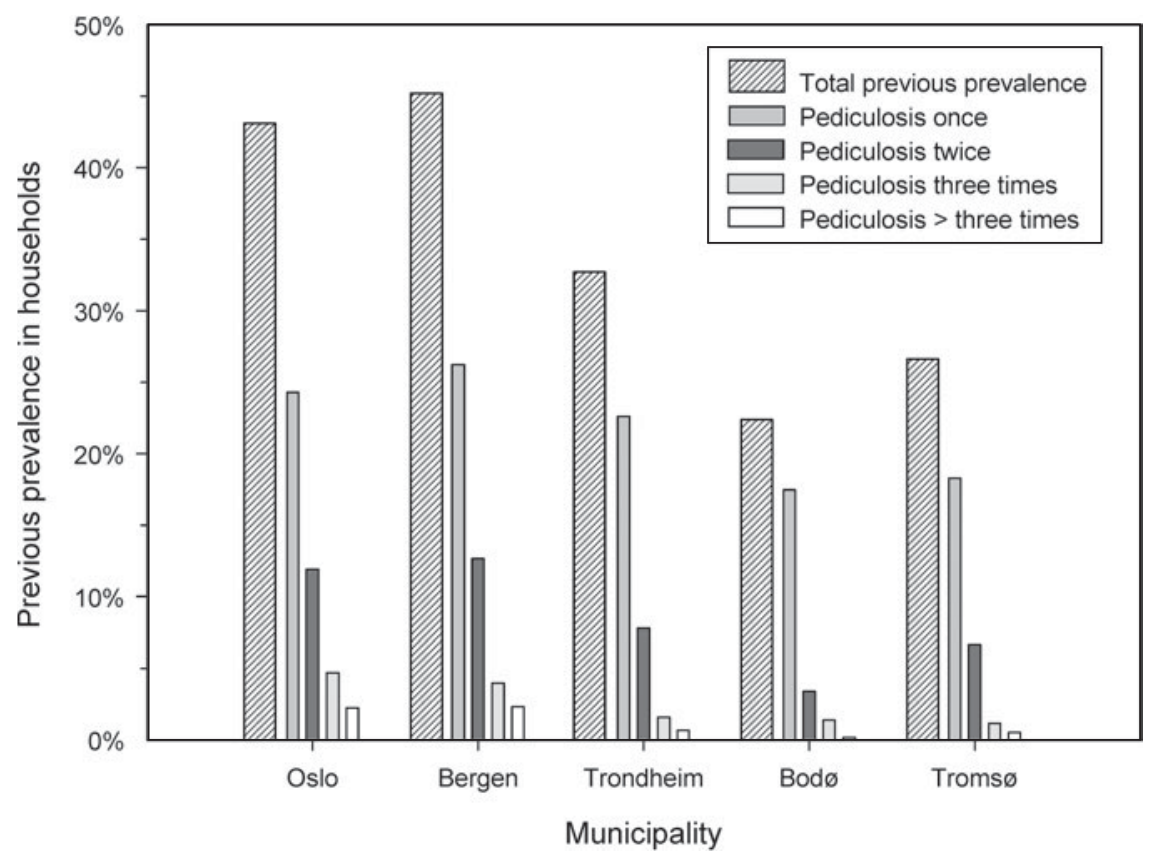

Fig. 2. Previous prevalence of head lice in households from different municipalities $(N=6026)$.

Which households have previously experienced head lice? The multivariate model (Table 5) indicates that households in Oslo and Bergen were more likely to have experienced pediculosis than those from the other municipalities. Trondheim had intermediate and higher previous prevalence compared to both 
Table 5. Multivariate, mixed-effect logistic regression model of previous prevalence of head lice among households with school as a random-effect variable

(Odds ratios are in relation to the first category of each variable. $N=5909$.)

\begin{tabular}{lllll}
\hline \hline Variable & $P$-value & Category & Prevalence $(n)$ & Odds ratio $(95 \%$-CI $)$ \\
\hline Number of household members & $0 \cdot 741$ & 2 or 3 persons & $29 \cdot 82 \%(1298)$ & 1 \\
& & 4 persons & $33 \cdot 79 \%(2820)$ & $0 \cdot 93(0 \cdot 67-1 \cdot 30)$ \\
& & $>4$ persons & $45 \cdot 39 \%(1791)$ & $1 \cdot 02(0 \cdot 57-1 \cdot 83)$ \\
Number of children (persons $<18$ years) & $0 \cdot 011$ & 1 child & $26 \cdot 81 \%(1052)$ & 1 \\
& & 2 children & $34 \cdot 70 \%(3152)$ & $1 \cdot 53(1 \cdot 16-2 \cdot 01)$ \\
& & 3 children & $44 \cdot 88 \%(1406)$ & $2 \cdot 21(1 \cdot 30-3 \cdot 76)$ \\
& & $>3$ children & $49 \cdot 16 \%(299)$ & $2 \cdot 50(1 \cdot 39-4 \cdot 49)$ \\
Number of adults (persons $>18$ years) & $0 \cdot 193$ & 1 adult & $34 \cdot 13 \%(835)$ & 1 \\
& & 2 adults & $36 \cdot 68 \%(4749)$ & $0 \cdot 88(0 \cdot 68-1 \cdot 14)$ \\
& & $>2$ adults & $38 \cdot 77 \%(325)$ & $1 \cdot 07(0 \cdot 65-1 \cdot 76)$ \\
Municipality & & Tromsø & $26 \cdot 63 \%(950)$ & 1 \\
& & Bodø & $22 \cdot 22 \%(585)$ & $0 \cdot 86(0 \cdot 57-1 \cdot 31)$ \\
& & Trondheim & $32 \cdot 56 \%(1425)$ & $1 \cdot 44(0 \cdot 96-2 \cdot 18)$ \\
& & Bergen & $45 \cdot 28 \%(1442)$ & $2 \cdot 24(1 \cdot 59-3 \cdot 15)$ \\
Number of students per school & & Oslo & $43 \cdot 33 \%(1507)$ & $2 \cdot 27(1 \cdot 51-3 \cdot 42)$ \\
& & & & $1 \cdot 00(1 \cdot 00-1 \cdot 00)$ \\
\hline \hline
\end{tabular}

Table 6. Multivariate, mixed-effect logistic regression model of previous prevalence of head lice among onechild households with school as a random-effect variable

(Odds ratios are in relation to the first category of each variable. $N=919$. )

\begin{tabular}{|c|c|c|c|c|}
\hline Variable & $P$-value & Category & Prevalence $(n)$ & Odds ratio $(95 \%-\mathrm{CI})$ \\
\hline Grade & $<0 \cdot 001$ & $\begin{array}{l}\text { 1. grade } \\
\text { 2. grade } \\
\text { 3. grade } \\
\text { 4. grade } \\
\text { 5. grade } \\
\text { 6. grade } \\
\text { 7. grade }\end{array}$ & $\begin{array}{l}10 \cdot 95 \%(137) \\
14 \cdot 93 \%(134) \\
24 \cdot 41 \%(127) \\
30 \cdot 95 \%(126) \\
36 \cdot 43 \%(129) \\
34 \cdot 07 \%(135) \\
36 \cdot 64 \%(131)\end{array}$ & $\begin{array}{l}1 \\
1 \cdot 50(0 \cdot 72-3 \cdot 13) \\
2 \cdot 79(1 \cdot 39-5 \cdot 61) \\
4 \cdot 22(2 \cdot 13-8 \cdot 35) \\
4 \cdot 82(2 \cdot 47-9 \cdot 41) \\
4 \cdot 60(2 \cdot 36-8 \cdot 97) \\
5 \cdot 59(2 \cdot 86-10 \cdot 93)\end{array}$ \\
\hline Municipality & $0 \cdot 018$ & $\begin{array}{l}\text { Tromsø } \\
\text { Bodø } \\
\text { Trondheim } \\
\text { Bergen } \\
\text { Oslo }\end{array}$ & $\begin{array}{l}18 \cdot 67 \%(166) \\
16 \cdot 42 \%(134) \\
25 \cdot 49 \%(204) \\
30 \cdot 06 \%(163) \\
36 \cdot 51 \%(252)\end{array}$ & $\begin{array}{l}1 \\
0 \cdot 73(0 \cdot 34-1 \cdot 58) \\
1 \cdot 41(0 \cdot 65-3 \cdot 06) \\
1 \cdot 84(0 \cdot 94-3 \cdot 60) \\
2 \cdot 52(1 \cdot 19-5 \cdot 37)\end{array}$ \\
\hline Sex & $0 \cdot 002$ & $\begin{array}{l}\text { Male } \\
\text { Female }\end{array}$ & $\begin{array}{l}22 \cdot 07 \%(444) \\
31 \cdot 16 \%(475)\end{array}$ & $\begin{array}{l}1 \\
1 \cdot 65(1 \cdot 20-2 \cdot 26)\end{array}$ \\
\hline Number of students per school & $0 \cdot 819$ & & & $1 \cdot 00(1 \cdot 00-1 \cdot 00)$ \\
\hline
\end{tabular}

Bodø and Tromsø. The presence of more children in a household increased the risk of previous pediculosis, whereas the total number of household members, number of adults in a household and number of students per school had no significant effect. Again, school included as random-effect variable improved the multivariate model significantly (estimate: $0 \cdot 292$, $P<0.001)$ indicating that school on its own was an important risk factor for households having experienced head lice.

Influence of child age on previous household pediculosis. To investigate whether the age of elementary school children was important for previous experience of pediculosis in a household, 2 different analyses were performed. First, one-child households (households with only 1 person under 18 years of age) were analysed separately. The multivariate model (Table 6) with school as a random-effect variable (estimate: $0 \cdot 361, P=0 \cdot 018$ ) demonstrated that households with a child in third grade had a higher risk of previous pediculosis compared to those with a first- or second-grade child $(P=0 \cdot 060)$. Households with a child in fourth to seventh grade did not differ in risk of pediculosis. Hence, the largest difference in previous pediculosis was between households with a child in second and third grade. Households with a girl student had significantly higher previous prevalence of head lice than households with a boy. 
Table 7. Multivariate, mixed-effect logistic regression model of previous prevalence of head lice among households with school as a random-effect variable and grade of oldest elementary school child in the household included as a predictor variable

(Odds ratios are in relation to the first category of each variable. $N=4016$.)

\begin{tabular}{|c|c|c|c|c|}
\hline Variable & $P$-value & Category & Prevalence $(n)$ & Odds ratio $(95 \%-\mathrm{CI})$ \\
\hline $\begin{array}{l}\text { Grade of oldest elementary school child } \\
\text { in the household }\end{array}$ & $<0 \cdot 001$ & $\begin{array}{l}\text { 1. grade } \\
\text { 2. grade } \\
\text { 3. grade } \\
\text { 4. grade } \\
\text { 5. grade } \\
\text { 6. grade } \\
\text { 7. grade }\end{array}$ & $\begin{array}{r}9 \cdot 53 \%(493) \\
16 \cdot 42 \%(475) \\
26 \cdot 64 \%(563) \\
34 \cdot 60 \%(578) \\
41 \cdot 14 \%(632) \\
41 \cdot 03 \%(624) \\
44 \cdot 09 \%(651)\end{array}$ & $\begin{array}{l}1 \\
2 \cdot 11(1 \cdot 42-3 \cdot 13) \\
3 \cdot 80(2 \cdot 64-5 \cdot 47) \\
5 \cdot 65(3 \cdot 95-8 \cdot 07) \\
7 \cdot 47(5 \cdot 26-10 \cdot 61) \\
7 \cdot 55(5 \cdot 32-10 \cdot 72) \\
8 \cdot 43(5 \cdot 94-11 \cdot 98)\end{array}$ \\
\hline Municipality & $<0 \cdot 001$ & $\begin{array}{l}\text { Tromsø } \\
\text { Bodø } \\
\text { Trondheim } \\
\text { Bergen } \\
\text { Oslo }\end{array}$ & $\begin{array}{l}23 \cdot 20 \%(651) \\
18 \cdot 43 \%(407) \\
29 \cdot 04 \%(978) \\
38 \cdot 23 \%(939) \\
39 \cdot 29 \%(1041)\end{array}$ & $\begin{array}{l}1 \\
0 \cdot 80(0 \cdot 48-1 \cdot 34) \\
1 \cdot 43(0 \cdot 87-2 \cdot 37) \\
2 \cdot 16(1 \cdot 42-3 \cdot 28) \\
2 \cdot 46(1 \cdot 49-4 \cdot 04)\end{array}$ \\
\hline Number of children (persons $<18$ years) & $0 \cdot 439$ & $\begin{array}{l}1 \text { child } \\
2 \text { children } \\
3 \text { children } \\
>3 \text { children }\end{array}$ & $\begin{array}{l}26 \cdot 44 \%(904) \\
31 \cdot 15 \%(2212) \\
38 \cdot 26 \%(771) \\
42 \cdot 64 \%(129)\end{array}$ & $\begin{array}{l}1 \\
1 \cdot 26(0 \cdot 89-1 \cdot 79) \\
1 \cdot 75(0 \cdot 80-3 \cdot 81) \\
1 \cdot 99(0 \cdot 84-4 \cdot 69)\end{array}$ \\
\hline Number of adults (persons $>18$ years) & $0 \cdot 600$ & $\begin{array}{l}1 \text { adult } \\
2 \text { adults } \\
>2 \text { adults }\end{array}$ & $\begin{array}{l}32 \cdot 63 \%(616) \\
31 \cdot 54 \%(3297) \\
35 \cdot 92 \%(103)\end{array}$ & $\begin{array}{l}1 \\
0 \cdot 88(0 \cdot 65-1 \cdot 20) \\
0 \cdot 99(0 \cdot 49-1 \cdot 99)\end{array}$ \\
\hline Number of household members & $0 \cdot 917$ & $\begin{array}{l}2 \text { or } 3 \text { persons } \\
4 \text { persons } \\
>4 \text { persons }\end{array}$ & $\begin{array}{l}28 \cdot 86 \%(1102) \\
30 \cdot 29 \%(1994) \\
38 \cdot 70 \%(920)\end{array}$ & $\begin{array}{l}1 \\
0 \cdot 93(0 \cdot 62-1 \cdot 41) \\
0 \cdot 84(0 \cdot 36-1 \cdot 94)\end{array}$ \\
\hline Number of students per school & $0 \cdot 820$ & & & $1(1 \cdot 00-1 \cdot 00)$ \\
\hline
\end{tabular}

The second analysis was based on households without children in junior high school or members aged 16-20 years. The grade of the oldest elementary school child in a household was included as a predictor variable in the multivariate model (Table 7) with school as a random-effect variable (estimate: $0 \cdot 347, P<0 \cdot 001)$. Similar to the analysis of one-child households, the largest change in previous pediculosis was between households where the oldest child was in second or third grade. The increase between grades in each of the first five grades was significant, while differences between fifth, sixth and seventh grade were small and not significant.

\section{DISCUSSION}

This study investigates the present prevalence of head lice among primary school children and other age groups and the previous prevalence among their households. Both approaches demonstrated that the risk of contracting head lice was influenced by school attended, and significant differences in prevalence of previous infestations were observed across municipalities. Furthermore, the risk of pediculosis increased with the number of children in a household and was highest for children in the third grade. Analyses also showed that present prevalence was higher in elementary school children than in younger and older persons, and that households with only a girl student had a higher prevalence of previous infestation than households with only a boy student.

\section{Spatial habitat structure in municipalities, schools and households}

As head lice are in close contact with their host during all life stages, the species differs from many other ectoparasites that spend longer periods away from their host such as fleas, sand flies and ticks (Krasnov et al. 2002). For head lice, persons with close social interactions can be viewed as discrete, hierarchical nested habitat patches on different spatial scales. A patch can comprise just one host or a group of hosts defined by households, friends, class, grade, school, closely spaced schools in a municipality or whole municipalities. To investigate population dynamics properly and reduce the risk of interpretational errors in this type of hierarchical habitat system, more than one spatial scale should be considered (Wiens, 1989; Rukke and Midtgaard, 1998).

Schools and municipalities. Although the distribution of habitat patches over time and space probably influences the population dynamics of head lice, such spatiotemporal distribution of persons has rarely been used to explain the prevalence patterns of pediculosis. Previous studies have mainly 
focused on individual characteristics like sex, hair type and age. However, Willems et al. (2005) found that clustering of students into classes and schools was more important than single-student characteristics. The present study shows a similar tendency regarding clustering of students into schools: including school as a random effect variable was highly significant in analyses of both present and previous head lice prevalence. The clustering of students into classes was also found to be important for prevalence in an Australian study (Speare and Buettner, 1999).

In the present study, the more densely populated municipalities (Oslo and Bergen), whether measured by the number of schools, school size, inhabitant density or urban settlement area, had higher previous prevalence than the less densely populated municipalities (Tromsø and Bodø). This is in accordance with parasitological predictions of increased transmission rates in denser host populations (Arneberg et al. 1998; Krasnov et al. 2002; Stanko et al. 2006). An alternative explanation of such a pattern follows metapopulation theory (e.g. Hanski and Thomas, 1994; Hanski, 1999) which predicts that larger, less isolated assemblages of hosts have higher parasite prevalence than smaller, more isolated assemblages.

In addition to this, more densely populated municipalities may have a larger number of inhabitants travelling abroad to areas with higher prevalence, which might increase influx of new head lice into the system compared to less densely inhabited areas. More densely populated municipalities are also likely to contain a higher number of persons not receiving appropriate treatment for head lice and repeatedly infesting others. These individuals may be regarded as permanent sources in a source-sink system (Pulliam, 1988).

Household size. Habitat patch size also seems important at the household level, as several studies have found that risk of pediculosis increased with the number of household members (Willems et al. 2005; Balcioglu et al. 2007; Motovali-Emami et al. 2008; Soultana et al. 2009). In the present study we found that the risk of pediculosis increased with the number of children in a household rather than with total household members. As elementary school children have a higher incidence of head lice than other age groups, this finding is unsurprising. Mossong et al. (2008) found that the number of daily contacts with other persons is higher for members of large households compared to small households. Households with many children in elementary school are likely to have higher total contact rates than those with few children, increasing the risk of bringing head lice to the household. Once an infestation is established, the likelihood of head lice extinction may also be reduced in a household with many children as more individuals suffer simultaneously from pediculosis.
Interestingly, children in one-child households had significantly higher risk of pediculosis than children in families with 2 elementary school children. Possibly, children without siblings interact more with children from other households due to a lack of playmates at home, leading to increased overall contact rates and risk of pediculosis.

Re-colonization. The present study indicates that re-colonization, or re-infestation, occurs frequently. Elementary school children had a higher risk of pediculosis if their household had experienced pediculosis previously, and more than one-third of the households with previous infestations had experienced head lice more than once. Re-colonization is not unexpected if a child is part of a group of interacting children in which simultaneously detecting and eradicating head lice are difficult. An infestation can persist for a long time if inspection and treatment are not synchronized (Ibarra et al. 2009).

\section{Influence of age, school grade and sex}

The higher prevalence of head lice in elementary school children than in other age groups is in accordance with other studies (Burgess, 1995; Roberts, 2002; Leung et al. 2005). Changes in social interactions with age can be an important element explaining such a pattern. Mossong et al. (2008) found that contact rates were higher among school children compared to other age groups in all European countries investigated. Also, school children tended to mix more with persons of the same age, and contacts at a school or home were more intimate than at a work place.

In the present study, the infestation rates also changed through the grades of elementary school. The largest increase in risk of pediculosis was observed from second to third grade, and the overall risk increased to the fifth grade before leveling off. Older children may have established their social relations to a greater extent, interacting with fewer students which lead to reduced head-to-head contact. In addition, $60 \%$ of first- to fourth-grade children in Norway participate in day care facilities both before and after school (Ministry of Local Government and Regional Developement, 2010), further increasing the number of interactions among younger compared to older students.

Households with a girl had a higher risk of pediculosis than households with a boy. This is in accordance with other studies, which have shown higher prevalence in girls than boys (e.g. Counahan et al. 2004; Catala et al. 2005; Willems et al. 2005; Motovali-Emami et al. 2008; Toloza et al. 2009). Social interactions may again explain these differences (Heukelbach, 2010), as contacts between boys 
are assumed to be more brief than for girls, who have more prolonged and closer head contacts (Burgess, 1995; Speare and Buettner, 1999).

\section{Limitations of the study}

If the number of participants in a study is low, a selection bias may affect results (e.g. Eaker et al. 1998). About $50 \%$ of the invited elementary school students participated in this study, which is approximately the same, or somewhat higher, than other head lice studies based on caretaker feedback (Counahan et al. 2004, 2007; Soultana et al. 2009). However, we cannot rule out the possibility that our results may not represent the total population.

The method of self-checking household members for head lice might be criticized as an inaccurate method of pediculosis detection. However, of 42 plastic bags with suspected head lice returned from households in the present study, 36 included head lice and 3 included embryonated eggs, whereas 3 included only empty eggs (Rukke et al., unpublished observations). Additionally, although a more precise detection method could have resulted in higher prevalence figures, the relative differences between different categories of each variable were unlikely to vary, and the main conclusions from the present study would therefore have been preserved.

The statistical tests regarding previous prevalence among households have greater statistical power than those of present prevalence due to the higher number of reported infestations. However, as a retrospective investigation, the former has more inherent uncertainty than the latter due to the time lag between responses and the predictors investigated. Nevertheless, the overall results achieved by the two approaches support each other, which strengthen the conclusions.

\section{Conclusions}

Present pediculosis among household members in this study was below $1 \%$, but more than one-third of households had suffered previously from pediculosis. Thus, head lice infestations may be regarded as a significant community health problem among Norwegian households with elementary school children. The results further indicate that personal characteristics such as age and sex as well as the density of hosts at several spatial scales influence head lice prevalence. To increase our knowledge of head lice population dynamics, more empirical studies focusing on the spatial distribution of hosts at multiple scales are necessary, as well as the development of epidemiological models such as that developed by Stone et al. (2008). A better understanding of population dynamics and epidemiology will facilitate public guidelines to oppose pediculosis.

\section{ACKNOWLEDGEMENTS}

We would like to thank Aage Tverdal and Anders Aak for valuable comments on the manuscript. Aage Tverdal also provided valuable statistical advice. Participating households, staff of the schools and Nina Huynh are thanked for their effort with data collection.

\section{REFERENCES}

Altizer, S., Nunn, C. L., Thrall, P. H., Gittleman, J. L., Antonovics, J., Cunningham, A.A., Dobson, A.P., Ezenwa, V., Jones, K. E., Pedersen, A. B., Poss, M. and Pulliam, J. R. C. (2003). Social organization and parasite risk in mammals: Integrating theory and empirical studies. Annual Review of Ecology Evolution and Systematics 34, 517-547.

Arneberg, P., Skorping, A., Grenfell, B. and Read, A. F. (1998). Host densities as determinants of abundance in parasite communities. Proceedings of the Royal Society of London, B 265, 1283-1289.

Balcioglu, I. C., Kurt, O., Limoncu, M.E., Dinc, G., Gumus, M., Kilimcioglu, A. A., Kayran, E. and Ozbilgin, A. (2007). Rural life, lower socioeconomic status and parasitic infections. Parasitology International 56, 129-133.

Burgess, I. F. (1995). Human lice and their management. In Advances in Parasitology (ed. Baker, J. R., Muller, R. and Rollinson, D.), pp. 271-341 Academic Press Limited, San Diego, CA, USA.

Burgess, I. F. (2009). Current treatments for pediculosis capitis. Current Opinion in Infectious Diseases 22, 131-136.

Canyon, D. V., Speare, R. and Muller, R. (2002). Spatial and kinetic factors for the transfer of head lice (Pediculus capitis) between hairs. Fournal of Investigative Dermatology 119, 629-631.

Catala, S., Junco, L. and Vaporaky, R. (2005). Pediculus capitis infestation according to sex and social factors in Argentina. Revista de Saude Publica 39, 438-443.

Counahan, M., Andrews, R., Buttner, P., Byrnes, G. and Speare, R. (2004). Head lice prevalence in primary schools in Victoria, Australia. Fournal of Paediatrics and Child Health 40, 616-619.

Counahan, M. L., Andrews, R.M., Weld, H., Helen, W. and Speare, R. (2007). What parents in Australia know and do about head lice. Rural and Remote Health 7, online. Web page: http://www.rrh.org.au Eaker, S., Bergstrom, R., Bergstrom, A., Adami, H. O. and Nyren, O. (1998). Response rate to mailed epidemiologic questionnaires: A population-based randomized trial of variations in design and mailing routines. American Fournal of Epidemiology 147, 74-82.

Falagas, M. E., Matthaiou, D. K., Rafailidis, P. I., Panos, G. and Pappas, G. (2008). Worldwide prevalence of head lice. Emerging Infectious Diseases 14, 1493-1494.

Gratz, N. G. (1997). Human Lice. Their Prevalence, Control and Resistance to Insecticides. A Review 1985-1997. World Health Organization, Geneva, Switzerland.

Hanski, I. (1999). Metapopulation Ecology, 1st Edn. Oxford University Press, New York, USA.

Hanski, I. and Thomas, C. D. (1994). Metapopulation dynamics and conservation - a spatially explicit model applied to butterflies. Biological Conservation 68, 167-180.

Heukelbach, J. (2010). Management and Control of Head Lice Infestations. UNI-MED Verlag AG, Bremen, Germany.

Ibarra, J., Fry, F., Wickenden, C., Jenner, M. and Franks, A. (2009). The impact of well-developed preventative strategies on the eradication of head lice. Perspectives in Public Health 129, 165-173.

Krasnov, B., Khokhlova, I. and Shenbrot, G. (2002). The effect of host density on ectoparasite distribution: An example of a rodent parasitized by fleas. Ecology 83, 164-175.

Leung, A. K., Fong, J. H. and Pinto-Rojas, A. (2005). Pediculosis capitis. Fournal of Pediatric Health Care 19, 369-373.

Margolis, L., Esch, G. W., Holmes, J. C., Kuris, A. M. and Schad, G. A. (1982). The use of ecological terms in parasitology (report of an ad hoc committee of the American society of parasitologists). The Fournal of Parasitology 68, 131-133.

Mbora, D. N. M. and Mcpeek, M. A. (2009). Host density and human activities mediate increased parasite prevalence and richness in primates threatened by habitat loss and fragmentation. Fournal of Animal Ecology 78, 210-218.

Ministry of Local Government and Regional Development (2010). Kommuneproposisjonen 2010. Stortingsproposisjon $n r .68$ (20082009). Web page: http://www.regjeringen.no/pages/2191078/PDFS/ STP200820090068000DDDPDFS.pdf 
Mossong, J., Hens, N., Jit, M., Beutels, P., Auranen, K., Mikolajczyk, R., Massari, M., Salmaso, S., Tomba, G.S., Wallinga, J., Heijne, J., Sadkowska-Todys, M., Rosinska, M. and Edmunds, W. J. (2008). Social contacts and mixing patterns relevant to the spread of infectious diseases. Plos Medicine 5, 381-391.

Motovali-Emami, M., Aflatoonian, M. R., Fekri, A. and Yazdi, M. (2008). Epidemiological aspects of Pediculosis capitis and treatment evaluation in primary-school children in Iran. Pakistan Fournal of Biological Sciences 11, 260-264.

Mumcuoglu, K. Y., Barker, S. C., Burgess, I. E., Combescot-Lang, C. Dalgleish, R. C., Larsen, K. S., Miller, J., Roberts, R. J. and Taylan-Ozkan, A. (2007). International guidelines for effective control of head louse infestations. Fournal of Drugs in Dermatology: $\mathscr{F D D} 6$, 409-414.

Mumcuoglu, K. Y., Gilead, L. and Ingber, A. (2009). New insights in pediculosis and scabies. Expert Review of Dermatology 4, 285-302.

Norwegian Mapping Authority (2010). Areal statistikk. Kommuner. Web page: http://www.statkart.no/nor/Land/Fagomrader/Arealer_og_tall/ Pedlex Norsk Skoleinformasjon (2010). Pedlex norsk skoleinformasjon. Offentlige grunnskoler i Norge. Web page: http://pedlex.no/4daction/ WA_Gruppe/?Gr=130\&TP=110113093023\#

Pulliam, H. R. (1988). Sources, sinks, and population regulation. American Naturalist 132, 652-661.

Roberts, R. J. (2002). Clinical practice. Head lice. New England Fournal of Medicine 346, 1645-1650.

Rukke, B. A. and Midtgaard, F. (1998). The importance of scale and spatial variables for the fungivorous beetle Bolitophagus reticulatus (Coleoptera, Tenebrionidae) in a fragmented forest landscape. Ecography 21, 561-572.

Sorci, G., deFraipont, M. and Clobert, J. (1997). Host density and ectoparasite avoidance in the common lizard (Lacerta vivipara). Oecologia 111, 183-188.
Soultana, V., Euthumia, P., Antonios, M. and Angeliki, R. S. (2009). Prevalence of pediculosis capitis among schoolchildren in Greece and risk factors: A questionnaire survey. Pediatric Dermatology 26, 701-705.

Speare, R. and Buettner, P. G. (1999). Head lice in pupils of a primary school in Australia and implications for control. International fournal of Dermatology 38, 285-290.

Stanko, M., Krasnov, B. R. and Morand, S. (2006). Relationship between host abundance and parasite distribution: inferring regulating mechanisms from census data. Fournal of Animal Ecology 75, 575-583.

Stanko, M., Miklisova, D., de Bellocq, J. G. and Morand, S. (2002).

Mammal density and patterns of ectoparasite species richness and abundance. Oecologia 131, 289-295.

StataCorp LP (2009). Stata. 11 ed. StataCorp LP.

Statistics Norway (2008). Barnehager, barn og ansatte, etter fylke. 2009. Web page: http://www.ssb.no/barnehager/arkiv/tab-2010-03-15-01.html

Stone, P., Wilkinson-Herbots, H. and Isham, V. (2008). A stochastic model for head lice infections. Fournal of Mathematical Biology 56, 743-763. Toloza, A., Vassena, C., Gallardo, A., Gonzalez-Audino, P. and Picollo, M. I. (2009). Epidemiology of Pediculosis capitis in elementary schools of Buenos Aires, Argentina. Parasitology Research 104 1295-1298.

Wang, Q., Qiu, J. M., Schanz, P. M., He, J. G., Ito, A. and Liu, F. J. (2001). Investigation of risk factors for development of human hydatidosis among households raising livestock in Tibetan areas of western Sichuan Province. Chinese Fournal of Parasitology and Parasitic Diseases 19, 93-96.

Wiens, J. A. (1989). Spatial Scaling in Ecology. Functional Ecology 3, 385-397.

Willems, S., Lapeere, H., Haedens, N., Pasteels, I., Naeyaert, J. M. and De Maeseneer, J. (2005). The importance of socio-economic status and individual characteristics on the prevalence of head lice in schoolchildren. European fournal of Dermatology 15, 387-392. 